\title{
LOS MANUSCRITOS ILUSTRADOS DE LA BIBLIOTECA DE LA JUNTA
}

\author{
Ana Isabel Beneyto Lozano
}

Haremos un primer acercamiento a cada uno de los manuscritos ${ }^{1}$ objeto de análisis: su catalogación, sus características, como el color de las tintas, ya que no podemos presentar las decoraciones en color; para después analizar, en un siguiente capítulo, las formas decorativas en conjunto. Nos extenderemos en las obras que nos parecen más interesantes y en los estudios que se hayan hecho sobre ellas.

A partir de ahora, cada manuscrito de la Junta se denominará como "J" y el número romano, como ya hiceron Asín y Ribera, que le corresponda, es decir, el manuscrito 5 de la Junta será: J. V.

No hemos analizado los ciento un manuscritos de la edición, sino que hemos seleccionado aquellos ilustrados, y de éstos los que nos parecía que dichas ilustraciones eran dignas de ser analizadas, aunque también hay algunos que podrían ser interesantes, este trabajo acabaría, si nos dedicáramos a todos, siendo de gran formato.

El manuscrito J. I es el primero del que vamos a empezar a hablar. Ha sido estudiado por bastantes investigadores, y ya lo hemos citado antes al hablar de los orígenes de la literatura aljamiada 2 . Se trata de una copia del Breviario Suní ("Alquiteb Segoviano. Breviario Çuní"), cuyo autor es "El muftí alfaquí de la Aljama de Segovia, Iça de Gemir"3. Está fechado en 1492, con tinta negra con epígrafes en rojo, en lengua aljamiada; tiene correcciones marginales posteriores y decoraciones en márgenes.

Para Epalza y Wiegers, la obra de 'Îsà B. Ŷābir es de suma importancia para entender tanto la situación social de los moriscos como la literatura posterior, sobre todo su traducción del Corán al romance. Wiegers cree que po-

1. El sistema de catalogación que vamos a utilizar es el que sigue la reproducción electrónica de los CDs Manuscritos árabes y Aljamiados de la Junta, CSIC, citado en las primeras páginas.

2. G. WIEGERS, «'̄sà B. Ŷābir and the origins of Aljamiado literature», Al-Qanțara, XI-1, 1990, pp. 155-191.

3. M. Asín Palacios y J. Ribera y TARragó, Manuscritos árabes y aljamiados de la Biblioteca de la Junta, Madrid, 1912, pp. 1-2. 
dría haber sido alcalde de Segovia en algún momento, y que estuvo en contacto con sabios cristianos, como Juan de Segovia 4 .

Debió ser una obra muy importante en la época, ya que trata sobre moralidad, las obligaciones de un buen musulmán y acerca del derecho civil y penal; elementos muy importantes para aquellos moriscos que trataban de llevar una vida "correcta", dentro de un ambiente hostil y complicado. Explica además qué hace esta obra en la "lengua de los infieles", por qué los moriscos españoles habían olvidado la lengua de sus antepasados, y que era necesario volverles a explicar "su ley en la lengua que usaban entonces" 5 .

Wiegers nos dice que hay cinco copias de esta obra: dos de la Junta, CSIC (ésta y la número LX' ${ }^{6}$ ); dos en la Biblioteca Nacional de Madrid (2076 y 6016) y la de la Real Academia de la Historia, número $S 3^{7}$.

El número J. III de esta colección es una obra de miscelánea con azoras alcoránicas, textos profanos y de derecho y moral, como la historia de 'Umar, gran compañero fiel del profeta, famoso por su "austeridad y rígida justicia" o la historia de Carcayona, una chica que su fidelidad a Dios la llevó a la felicidad total $^{8}$. Datado hacia el siglo XVI. Letras en tinta negra y epígrafes en rojo y amarillo. Escrito de forma bilingüe. Igualmente, el J. IV es un códice de miscelánea, con obras moralizantes, de la vida y muerte del profeta, el Día del Juicio, etc. Así como la famosa obra del "Baño de Zarieb", estudiado por Saavedra como el "El alhadiz del Baño de Zarieb" ${ }^{9}$, donde vemos una historia mundana, ambientada en la sociedad andalusí, exactamente en la Córdoba del siglo X acondicionada a los gustos moriscos. Realizado entre los siglos XV y XVI, tinta negra, epígrafes en rojo y, algo que nos interesa, los encabezamientos en varios colores.

El J. VI es un manuscrito que enlaza con la tradición oriental. Se trata de una copia del libro del gran sabio al-Samarqandi. Es exactamente la traducción a la lengua castellana, en aljamiado, de algunos de los capítulos. Realizado en una fecha muy significativa, en 1601, a punto de ser decretada la expulsión de los moriscos de Aragón. Editada por Brockelmann, dice al principio "que la copia está hecha por un tal Mohammed, escribano mayor". Fue una obra que

4. Parece que Juan de Segovia pidió a 'Īsà B. Ŷābir que tradujera el Corán, para más información ver D. CABANELAS, «Juan de Segovia y el primer Alcorán trilingüe», Al-Andalus, XIV, 1949. Y del mismo autor Juan de Segovia y el problema islámico, Madrid, 1952.

5. M. Asín Palacios y J. Ribera y TARragó, op. cit., pp. 1-2.

6. Esta obra está escrita en castellano, con caracteres latinos y algunas decoraciones que después citaremos.

7. G. WIEGERS, op. cit., p. 156.

8. A.G. GHEJNE, «La Literatura Aljamiada», pp. 350-352. Ver SAAVEDRA, Discurso en la Real Academia de la Historia, Madrid, 1878, pp. 164-168.

9. En Mundo Ilustrado, 86, 1881. También Galmés de Fuentes hace una edición crítica de la obra, donde habla de la historia de "París y Viana". Y Asín Palacios nos informa de un posible original oriental, árabe. 
debió de ser casi un best seller, ya que tras ser traducida por un morisco aragonés en el siglo XVI, y ser una obra que habla de los buenos comportamientos, las prácticas y la ley religiosas, resultaría ser muy valorado por los moriscos, viniendo estos "consejos" de un sabio del oriente islámico. Este erudito oriental era especialista en el arte de la discusión, pero también escribe obras de geometría, lógica o astronomía; fue fundador de una escuela de teología que después se consideró precursora de una de las dos escuelas sunnī de Kalām.

El J. VIII es una obra habitual de la literatura aljamiada y que, a nuestro parecer, es una muestra de la búsqueda de autenticidad y rectitud del musulmán. Se llama "Castigos para lax gentex", estudiado por María José Fernández en su Tesis Doctoral ${ }^{10}$. Galmés de Fuentes nos explica que este tipo de literatura sobre castigos sirve para encaminar al buen musulmán, advertirle de lo que le puede pasar si no lleva una vida correcta, justa y prudente. Pertenece al género de la "wașiyya", que significa "testamento, recomendación o consejo"; Luzmān alHakìm fue uno de los escritores más importantes de este género, sus consejos llegaron de forma oral hasta que aparece escrito en la literatura aljamiada ${ }^{11}$.

En el J. XII, del siglo XVI, encontramos otra obra de miscelánea, en la que destaca un tratado al principio ${ }^{12}$ en el que explica cómo leyendo, copiando y llevando consigo fragmentos o partes del Corán, devociones, alabanzas, etc., se conseguirá una mejor vida y beneficios ${ }^{13}$; además de consejos para una correcta lectura del Corán, según el método naftí. Sus características son: tinta en negro con los epígrafes en trazo más grueso, sin colores, en aljamiado; en cambio el J. XIV ${ }^{14}$ es en árabe, traducido al aljamiado, donde además se nos informa incluso de los copistas.

Algunas azoras del Corán se encuentran en esta copia del siglo XVI, J. XVI, en epigrafía árabe, en tinta negra con las vocales en rojo y epígrafes en amarillo. La pregunta es cómo mantener el Islam en estos territorios ya no gobernados por musulmanes, cómo hacer llegar la doctrina y no perder adeptos. Los escritos debieron tener, y nunca mejor dicho, un papel muy importante a la hora de mantener el espíritu musulmán, a través de tradiciones, consejos y por supuesto, copias del Corán. En la guarda nos da un dato curioso: "En el año de mil quinientos y treinta y trex y medio, el rey Don Calrrox mandó que se hiciesen lox morox del reino de Balançia y de Aragón Cristianox o se fuesen de la tierra". El J. XXXIV, del siglo XVI, también consta de azoras alcoránicas, de él traeremos algunas de sus decoraciones.

10. Libro de los Castigos (ms. n. ${ }^{\circ} 8$ de la Biblioteca de la Junta), Oviedo, 1987.

11. A. Galmés de FuENTES, «Castigos», Estudios sobre la literatura aljamiado-morisca, p. 123.

12. Al igual que el existente en la Biblioteca Nacional de Madrid (5081).

13. A.G. GHEJNE, op. cit., p. 347.

14. M.J. CERVERA FrAS, «Rasgos lingüísticos aragoneses en el texto aljamiado del ms. J.14», en Hommage à l'Ecole d'Oviedo d'Etudes Aljamiado, dirección prof. Abdeljelil Temimi, Túnez, Fondation Temimi pour la Recherche Scientifique et l'Information, 2003. 
El J. XVII, escrito en árabe todo en tinta negra, se trata de una obra sobre temas religiosos, como los nombres de Dios. Sin datar, parece ser mudéjar, de finales del siglo XIV. El J. XVIII contiene azoras alcoránicas del siglo XVI, bilingüe árabe y aljamiada, cuya letra es más fina. Los comentarios de los alfaquíes parecen ser en este Corán más amplios que en otros manuscritos similares de la misma colección. Codera nos dice que "este códice, cuyas partes llevan los números 18 y 92, es el segundo tomo de una obra de Derecho, extractada de los libros de los jurisconsultos Mohammad ben Abd-Allah beli Abu Zamanin (español), Mohammad ben Ahmed ben Al-Aththar, Ahmed ben Çaîd Al-Hindi y Muza ben Ahmed conocido por Al-Watid: coleccionó esta obra el faquih AbuMohammad Abd-Allah ben Abde-l-Wahid el fihri"15.

El "Libro de Dichox Marabillosox", J. XXII, es una obra que podríamos enmarcar dentro de la literatura más popular. Escrita en aljamiado en tinta negra y epígrafes rojos. Dentro de un mundo adverso, donde el día a día se empieza a hacer más complicado y duro de llevar, las esperanzas de una vida mejor se van a afianzando en las mentes moriscas. Así las supersticiones, las creencias en elementos superiores, las cábalas, etc., se convierten en elementos que ayudan a la esperanza y a aliviar los males. Este manuscrito ha sido estudiado por Ana Labarta; contiene muchos dichos, refranes, sortilegios, fórmulas mágicas, también sobre astrología y sus posibles pronósticos, y en general, mecanismos que, a veces, se mantienen en la historia de la vida popular. Sirven para conseguir bien de amores, echar la mala suerte o los demonios de casa, sanar animales, conseguir lo que uno quiera, etc.

El manuscrito J. XXIII (al igual que el J. XXX) se enmarca también dentro de las creencias populares, ya que trata de una "letanía para pedir agua". Datado en el siglo XVI, podemos plantearnos si quizás habría problemas de sequías como en la época actual. Está escrito en aljamiado con los mismos colores que el J. XII. Es una obra de rogativas, muy habituales en el mundo árabe, lo que Galmés de Fuentes denomina "Remedios contra la Naturaleza".

El siguiente manuscrito en la catalogación, el J. XXIV, es un códice de miscelánea de varias materias. Contiene desde cuentas de un ganadero, oraciones, azoras alcoránicas, tradiciones, consejos para la oración, etc. Está escrito en aljamiado y árabe, en negro con vocales rojas. El J. XXV también es un códice de miscelánea con "azoras alcoránicas bilingües y predicaciones en aljamiado", escrito con el típico formato de letra negra, vocales rojas y epígrafes en amarillo. Ambos son del siglo XVI, aunque sin fechar.

El J. XXIX fue estudiado por Brokelmann, data del siglo XVI y está escrito en bilingüe árabe y aljamiado interlineal.

15. F. CODERA, "Almacén de un librero morisco descubierto en Almonacid de la Sierra», Boletín de la Real Academia de la Historia, V, Informes, Madrid, 1884, pp. 269-272. 
Soha Abboud, de esta Universidad, ha estudiado el manuscrito J. XXXIII, que trata del Al-Tafri de Ibn Al-Gallab, y es una copia del tratado de jurisprudencia islámica titulado "at-tafri del alfaqui basrense ibn al-gallab del siglo $x^{\prime 16}$; del que conservamos otra copia en la Biblioteca Pública de Toledo (T232) y otra en la Nacional de Madrid (4870), también analizado por la misma autora. Nos dice González" en su análisis que el autor es "Abulcásim Obadaila, hijo de Alhosaim, hijo de Albasam, hijo de Chalab de Basora, el Maliqui", y está fechado en el 993 de la Hégira, es decir, siglo XVII de nuestra era. En letra aljamiada negra, con epígrafes rojos y amarillos.

El J. XXXIX parece estar fragmentado, son cuadernos sueltos de varias materias. Sin fechar, pero aproximadamente del siglo XVI. Escritos en bilingüe, en tinta negra y algunas partes con epígrafes en rojo.

También se divide, pero en dos partes, el J. XLVI, por una parte diversos hadices y, por otra, copias de partes de diversos coranes. Sin datar, se fecha hacia el siglo XVI. Está en bilingüe y bastante deteriorado.

El manuscrito J. LI es quizás uno de los que contiene decoración más lograda, y que parece haber sido hecha por alguien que maneja el arte de la decoración de manuscritos. Teresa Losada ha estudiado este manuscrito como tema de su Tesis Doctoral, Estudios sobre Coranes Aljamiados, 1975, Barcelona. Se trata también de comentarios y traducciones, tafsīr, de un Corán. Citado por Vernet y López Lillo, el cual presenta "una traducción interlineal de cada aleya y cometario de las mismas"18, del siglo XVI; pero que, como característica curiosa, se traducen "las seis primeras azoras del Libro, dato de cierta importancia, ya que los Alcoranes conocidos reproducen más los textos de las últimas azoras, a partir de la $38^{\prime \prime 19}$.

En el manuscrito J. LIII nos encontramos con una obra titulada "alquiteb de preicax y exemplox y doctrinax para medeçinar el alma y amar la otra vida y aborreçer este mundo", es del siglo XVI sin fechar. Escrito en tinta negra, en aljamiado. Nos dice González que parece haber querido darnos un compendio de las leyes morales y ascéticas, para ponerlas al alcance de cualquier musulmán. Ghejne se refiere a esta obra dentro de los textos religiosos y jurídicos, y la define como "una cura para que el alma ame el más allá y menosprecie este mundo", parece una solución fácil para poder sobrellevar esta vida, sufrir lo que hay que sufrir y encontrar recompensa en la siguiente.

16. S. Abboud Haggar, El tratado jurídico de al-tafrî’ de Ibn al-Djallâb. Manuscrito aljamiado de Almonacid de la Sierra, edición, estudio, glosario y confrontación con el original árabe, Zaragoza, Institución Fernando el Católico, 1999.

17. Como ya hemos dicho, del análisis de las obras aljamiadas se ocupó este alumno de Asín Palacios y de Ribera.

18. J. Vernet y C. LÓpez Lillo, «Un manuscrito morisco del Corán», B. de la Real Academia de Buenas Letras de Barcelona, XXXV, 1973-1974. Además lo comparan con el J. XXV, por sus parecidos en la traducción del texto coránico en algunas aleyas.

19. Ibidem, p. 186. 
Parece que inéditas aún son las dos obras sobre devocionarios, J. LV y LVI. Junto con las traducciones del Corán, los comentarios de algunas de sus partes y las tradiciones del profeta, los devocionarios son otras de las obras aljamiadas más habituales, hay bastantes en la Biblioteca Nacional de Madrid. Los dos manuscritos de la Junta son del siglo XVI, en tinta negra y roja, escrita en árabe y aljamiado. La primera es una obra que parece haberla escrito un personaje no habituado a estas escrituras y en la segunda parece haber puesto más cuidado en su escritura.

El J. LVII es un conjunto de hadices, empezando por el hadiz de Nuh. La parte de debajo se conserva bastante mal, afectada por la humedad. En la última guarda del códice se nos informa: "principióse a doce días de la luna de chumedi legual que se contaba a beinte y uno de abril". Y termina con el día del juicio, tema que también aparece en el J. IV y II.

El manuscrito J. LXII es una obra bien conocida, estudiada y citada por varios investigadores, se titula "Tafçira", y es una copia de la obra del Mancebo de Arévalo $^{20}$; para Wiegers la influencia en su Breve Compendio de la santa ley y sunna le viene dada por el Breviario Sunni, del que anteriormente hemos hablado. Se trata de un manuscrito copiado por un autor que no es citado, en lengua aljamiada con tinta negra y epígrafes rojos y amarillos. Procede de Alcalá del Ebro, también de la provincia de Zaragoza, no de Almonacid de la Sierra, aunque se debió de llevar allí por alguna razón. Asín y Ribera dicen de esta obra: "Pero donde se muestra más evidente el prestigio que el nombre y las doctrinas místicas de Algazel llegaron a alcanzar en España, es en los nutridos folios de la Tafçria (ms. LXII) del Mancebo de Arévalo" ${ }^{21}$, y admiran el gran esfuerzo y valor de este mancebo, que no conoce el árabe ni puede leer los textos de Algazel, con el que escribe una obra de este tipo, citando al gran maestro, al que invoca constantemente.

Los siguientes manuscritos de la colección son en general folios sueltos que proceden de las tapas ${ }^{22}$ de los manuscritos, muchas están muy deterioradas e ilegibles de forma digital, así que sólo citaremos algunas por contener cierta decoración que nos haya llamado la atención: el J. LXXXVII, que corresponde a las hojas que daban forma a las tapas del manuscrito XXIV, son fragmentos alcoránicos, de religión, en árabe. El J. XCIII lo forman los folios del J. XXIX, en lengua castellana, árabe y aljamiada, bastante ilegible. Después el J. XCIV son los folios de las tapas del J. XXX, y contienen cuentas de gastos con

20. L.P. HARveY, «El Mancebo de Arévalo y la literatura Aljamiada», Actas del Coloquio Internacional sobre literatura aljamiada y morisca, Oviedo, 1978, pp. 21-41.

21. M. Asín Palacios y J. Ribera y TARragó, op. cit., p. XVI.

22. Las encuadernaciones moriscas de algunos manuscritos estaban formadas con hojas de libros y con papeles documentales más antiguos y en una nota al pie citan cómo el conocido morisco Mancebo de Arévalo cuenta este procedimiento en el manuscrito J. LXVII: "vio en Sigüenza que un encuadernador lo hacía", ibídem, p. XXVI. 
letra aragonesa del siglo XVI. Hay varios folios impresos sobre doctrina y sobre la historia de la conquista de Rodas.

En resumen, hemos tratado de explicar cada uno de los manuscritos de los que vamos a desglosar sus elementos decorativos. Podemos ver que la gran mayoría de los manuscritos decorados son de tema religioso, lo que nos acerca aún más a aquellos antecedentes andalusíes antes expuestos.

En el capítulo siguiente también haremos referencias a manuscritos aljamiados de otras colecciones, como algunas de Cataluña o la Real Academia de Madrid, por sus semejanzas decorativas y artísticas.

\section{ELEMENTOS DECORATIVOS}

Partiendo del formato de estudio que manejó Basilio Pavón Maldonado en sus obras sobre decoración geométrica y floral del arte hispanomusulmán ${ }^{23}$, en los que recoge multitud de elementos decorativos de arquitecturas, pinturas, maderas, yeserías, incluso de manuscritos, y los agrupa por sus formas, ya sean palmetas, flores, estrellas, etc., tomamos esta idea y lo que hacemos es separar cada uno de los elementos decorativos de estos manuscritos aljamiadosmoriscos, para relacionarlos entre sí y darles una denominación común para su mejor entendimiento y estudio.

Pretendemos así que cada una de las imágenes y elementos que mostremos ayude a los historiadores del arte a ver nuevas formas artísticas en un soporte casi olvidado por los especialistas en arte andalusí, y también a otros especialistas de otras disciplinas, que puedan ver y descubrir en este análisis formas que les sean familiares en sus manuscritos o que les puedan ayudar de alguna manera.

Fragmentaremos las imágenes según su forma y su función en el texto, así hablaremos de páginas completas, cartuchos, rosetones, manos, tréboles y cerezas, epígrafes adornados, símbolos y amuletos.

Sobre el arte de esta época se ha escrito bastante, lo que se ha denominado arte mudéjar ${ }^{24}$. El problema de esta denominación ha traído consigo bas-

23. B. Pavón Maldonado, El arte hispanomusulmán en su decoración floral, $2^{\mathrm{a}}$ ed., Madrid, Instituto de Cooperación con el Mundo Árabe, Instituto de Conservación y Restauración de Bienes Culturales, 1990. Id., El arte hispanomusulmán en su decoración geométrica, $2^{\text {a }}$ ed., Madrid, Instituto de Cooperación con el Mundo Árabe, Instituto de Conservación y Restauración de Bienes Culturales, 1989.

24. Se pueden consultar los tres volúmenes de G. BORRÁs GUALIS, El Arte mudéjar aragonés, Zara-

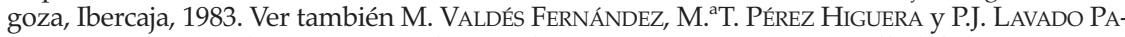
RADINAS, "Arte Mudéjar», Historia del Arte de Castilla y León, tomo IV, Valladolid, Junta Castilla y León, 1994, así como algunos de los artículos de las diferentes Actas del Simposio Internacional de Mudejarismo, organizado por el Centro de Estudios Mudéjares de Teruel. 


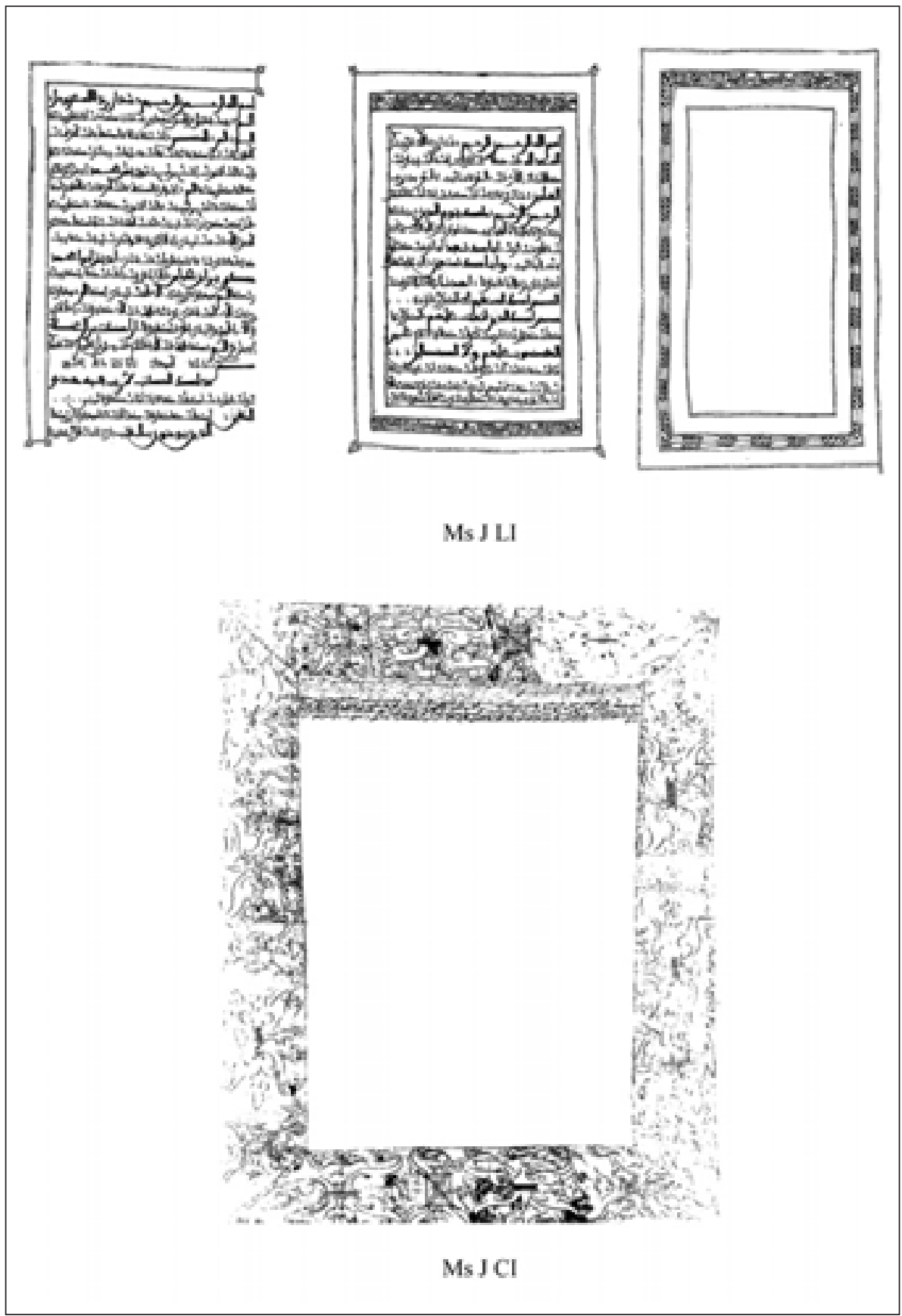

Ilustración I. 
tantes escritos, como sobre el nombre de arte mozárabe o arte de repoblación. Pero como nosotros no estamos aquí para lograr una nueva calificación para este arte, atenderemos a los trabajos ya realizados sobre este estilo, que para algunos autores tiene características originales, aunque para otros estas características vienen dadas sencillamente por unas circunstancias sociales y económicas, más que por unas motivaciones estilísticas o estéticas.

Hay que reconocer que una de las características más distintivas del arte de esta época es el uso del ladrillo y de la geometría, asociada directamente con la simetría, que se repite en pareces de iglesias y en sus característicos alminares. A esta geometría tan marcada, relacionada también con la austeridad, algunos investigadores la asumen como una intención de esoterismo ${ }^{25} \mathrm{o}$ con toda una carga religiosa mística, al mostrar una decoración simbólica y esquemática.

$\mathrm{Al}$ observar algunas de las fachadas, torres y otros objetos del arte de este momento, se encuentran elementos comunes a las decoraciones que se van a describir: entrelazos, elementos geométricos que se repiten creando formas simétricas, estrellas de seis y ocho puntas, motivos en sebka y romboidales, también, sobre todo en estucos o yeserías, motivos de palmetas, dobles y medias enfrentadas de forma muy esquemática siempre.

\section{CARTuchos. Ilustraciones I, II, III, IV, V y VI}

Esta denominación se ha dado para clasificar estas formas que se muestran a continuación. Y lo denominamos así por ser en general formas rectangulares en las que se suele insertar epigrafía o mostrarse decoraciones geométricas y florales en su interior.

Las clasificaremos según su función en el texto: por una parte tendremos cartuchos que sirven para ubicar un título, ya sea coránico o de otra temática. Por otra, cartuchos que se utilizan para separar capítulos o párrafos. También hay cartuchos de pequeño tamaño que sirven para finalizar frases que dejan espacios en blanco en el folio o para apoyar a la lectura. A veces estos pequeños cartuchos se insertan entre los párrafos, aumentando su separación.

De las primeras formas de cartuchos, Ilustración II, que insertan epigrafía en su interior aportamos los cartuchos de los manuscritos J. III, J. XIV, J. XVI, J. XXII, J. XXIII, J. XXV, J. XXXIX y J. LXXXIX. El primero (Ilustración II.a) es un cartucho que se completa en su lateral con un rosetón, que también contiene epigrafía, y pertenece a la primera página del manuscrito, es decir, es el título de la primera azora traducida. La segunda, del J. XIV (Ilustración II.b), en cambio, se complementa en su lateral por tres elementos que parecen frutales, tipo "piña".

25. A. RAMíREZ y C. USÓN, «Claves geométricas y decorativas para una lectura ideológica de las decoraciones mudéjares», Actas del IX Simposio Internacional de Mudejarismo, Teruel, Centro de Estudios Mudéjares, 2002, p. 369. 
El tercer ejemplo, del J. XVI (Ilustración II.c), también pertenece a la primera página del manuscrito, y resaltamos la decoración entrelazada de su interior, y al igual que el primero, un rosetón, separado en este caso, completa la decoración.

Del manuscrito J. XXII (Ilustración II.d) traemos un cartucho que muestra una decoración lateral diferente, finalizada con tres palmetas trilobuladas, que parecen hechas a mano alzada, aunque tratan de dar una idea de simetría, similar al que mostramos del J. XXIX (Ilustración II.g). De forma muy similar hizo el ilustrador del J. XXIII (Ilustración II.e) este cartucho, como los dibujos de los manuscritos J. III y XXII, aunque la decoración interior se forma con esa típica palmeta que vamos a encontrar en algunos manuscritos moriscos, entrelazados por un aro que sujeta y muestra una búsqueda de simetría. Exactamente igual es el cartucho del manuscrito J. XXV (Ilustración II.f).

Como el J. XXII y el XXIX, se nos muestra de forma más barroca el cartucho del manuscrito J. XXXIX (Ilustración II.h), en el que la decoración interior se forma por medio de entrelazos simétricos y la exterior por elementos florales, en un lateral y en las esquinas.

En la Bibliothèque Ibn Yūsuf de Marraquech se conserva un Corán almohade (431), en el que vemos una reminiscencia en estos manuscritos en las decoraciones, y por no traer otros manuscritos andalusíes, pues nos llevaría un trabajo completo analizar todos los antecedentes. Es decir, los moriscos no sólo copiaron los coranes, los comentaron y asimilaron, sino que también copiaron y asimilaron las formas que tenían sus antecesores de decorar dichos libros.

En el Institut d`Etudis Ilerdenses de la Diputació de Lleida se conserva un libro que es un devocionario, con talismán, plegaria, alfabeto, castas privadas y pequeña jarra ${ }^{26}$, de finales del siglo XV o principios del XVI, procedente también de un derribo de una casa en Serós, Lleida; en él vemos un cartucho de este tipo, rectangular, con una decoración interior en forma de malla o cuadrados iguales y un rosetón circular simple lateral. El amarillo, verde y rojo son los colores característicos en las decoraciones de esta época.

Hay formas que denotan que ya no hay grandes talleres, como en la Andalucía de los omeyas o nazaríes, pues no hay a veces detallismo, pinceladas de gran maestría o el uso de materiales ricos, como el oro o los colores más costosos como el azul. Pero es importante ver la intención estética de estas personas, su gusto por adornar y embellecer sus libros.

Para ejemplificar los cartuchos en los que no se inserta epigrafía mostramos el grupo de imágenes de la Ilustración III. Del manuscrito J. I (Ilustración III.a) traemos un cartucho que se inserta al principio de la obra. Se trata de un

26. J. GiRAlt (ed.), Joyas escritas. Los fondos bibliográficos árabes en Cataluña, Barcelona, Ed. Lunwerg, 2002, p. 204. 
elemento decorativo, que sencillamente da inicio al texto que encabeza. Igual que en la del J. XXXIX (Ilustración II.h), se decora en su exterior profusamente, a mano alzada se pintan en las esquinas unas formas florales, también habituales en estas decoraciones moriscas.

En otro devocionario "mudéjar o morisco"27 bilingüe procedente de Zaragoza, conservado en la Biblioteca de Cataluña, Barcelona (Ms. 1420), vamos a encontrar también en sus páginas cartuchos con decoración floral en su interior y en su exterior, así como en sus cuatro esquinas, del tipo de los cartuchos de la Imagen XIV (Ilustración III.g y III.h) de la Junta, sin epigrafía en su interior.

De los manuscritos J. XXII (Ilustración III.b) y J. XXIV (Ilustración III.c), traemos unos cartuchos más delgados, que sirven normalmente, para separar párrafos y partes importantes del texto. Estos tienen en su interior como decoración un sistema que parece imitar un motivo de cuerda o cable que rellena así la imagen y no la deja vacía. Pero a veces esa decoración se suple por motivos geométricos, habitualmente de entrelazo, como es el caso del cartucho del J. XXXIX (Ilustración III.d), de gran belleza y sutileza.

Usan también como elementos separadores los que mostramos en la Ilustración IV, pero que ya no vamos a denominar como cartuchos aunque lo integremos en esta parte. Son sencillas formas alargadas, cuyo tallo suele tener forma de cuerda o de entrelazo simple, y culmina en un motivo floral más o menos complejo. Por ejemplo, las dos primeras imágenes (Ilustración IV.a y IV.b) corresponden a los manuscritos J. XVII y XXII, donde vemos estas formas sencillas que imitan un elemento floral, que sirve para separar frases, párrafos o capítulos. El manuscrito XXX, en su tercera página, tiene un cartucho del tipo de los anteriores, pero en vez de finalizar en un motivo floral, contiene dos rosetones, uno mayor y otro menor (Ilustración IV.c).

También hay un formato que se repite en este tipo de elementos separadores, en el que el tallo se forma a través de una cuerda imaginaria que gira sobre sí misma y se complementa con una especie de pinchos o espinas y terminando en el mismo motivo floral que las anteriores. Para muestra de esto, el J. XXII (Ilustración IV.d) y el J. XXXIII (Ilustración IV.e), la primera de forma más alargada y terminada en dos palmetas trilobuladas, y la segunda igual, más estrecha, pero terminada en lo que parecen flores de lis.

Los dos últimos ejemplos (Ilustración IV.f y IV.g), de los manuscritos J. XXII y J. XIV, muestran también un prototipo de diseño que se repite en los manuscritos de la Junta, en diversos tamaños, pero con el mismo motivo de palmeta o media palmeta, contrapuesta y enfrentada, dando forma al elemento separador.

Como último desarrollo de estos cartuchos, en la Ilustración V tenemos las pequeñas formas que sirven para complementar frases que dejan espacios en blanco en el texto, acompañar algunos títulos, destacar ciertas frases y llamar la

27. Ibídem, pp. 196-197 (Ilustración 19). 


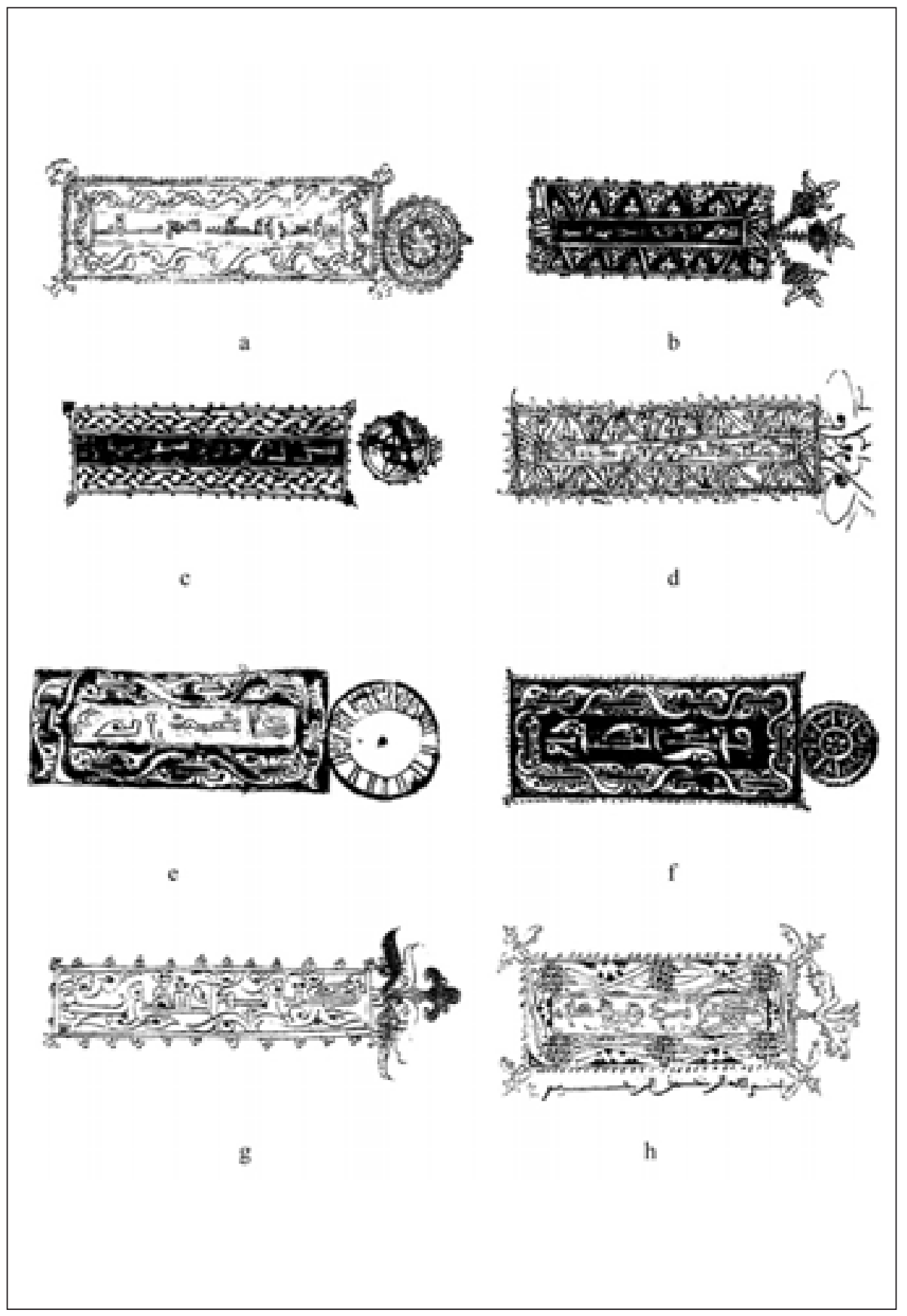

Ilustración II. 


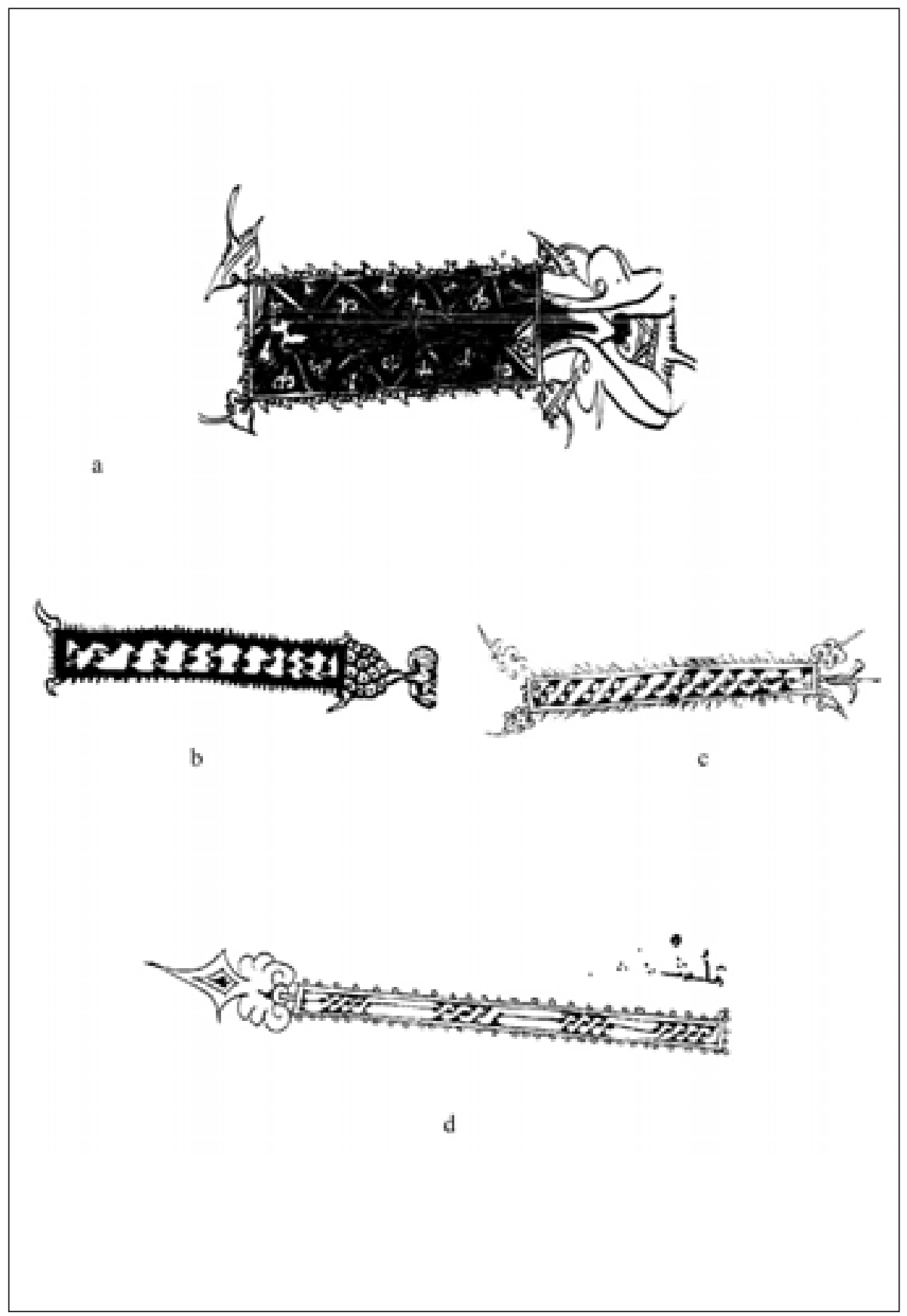

Ilustración III. 


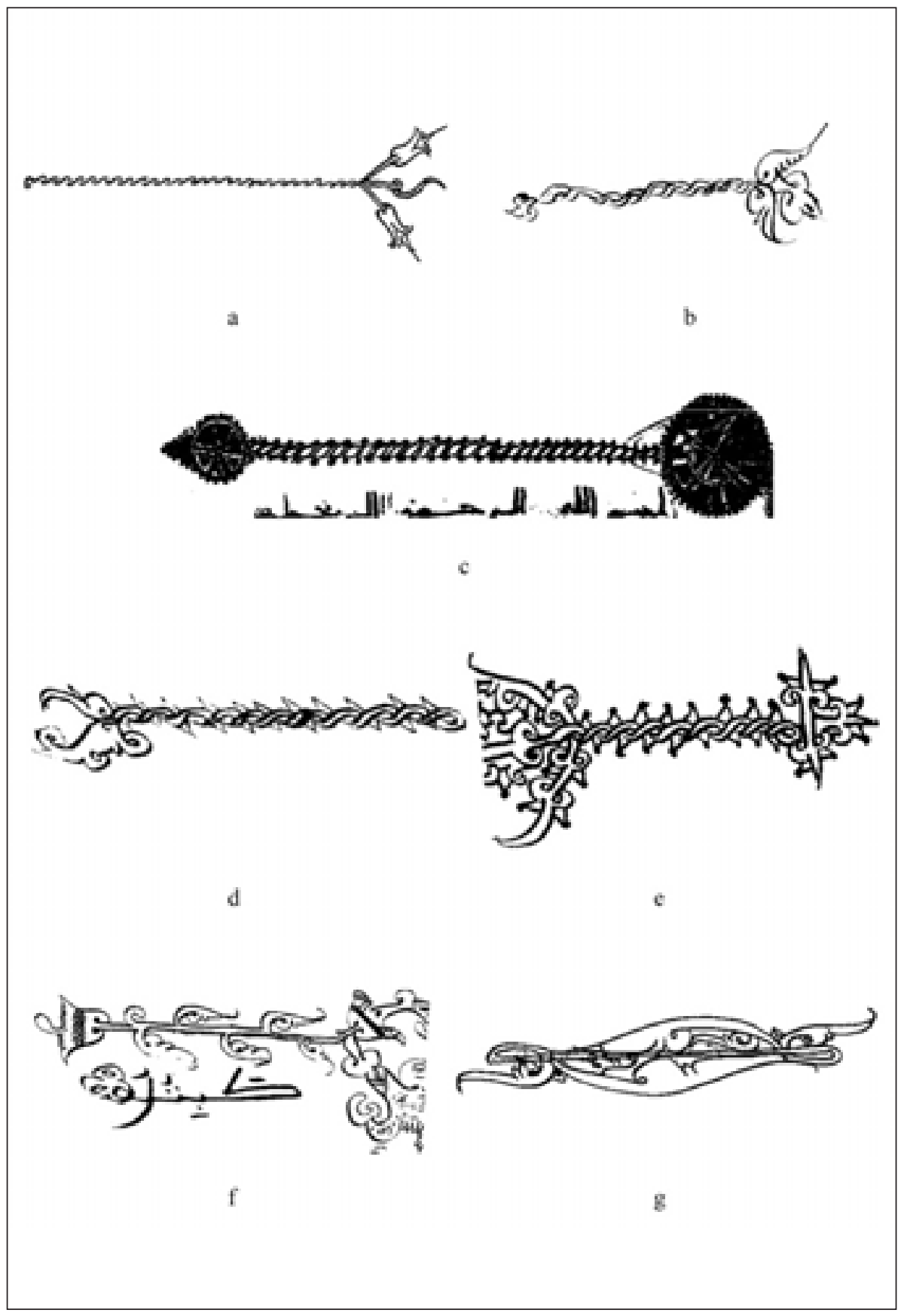

Ilustración IV. 


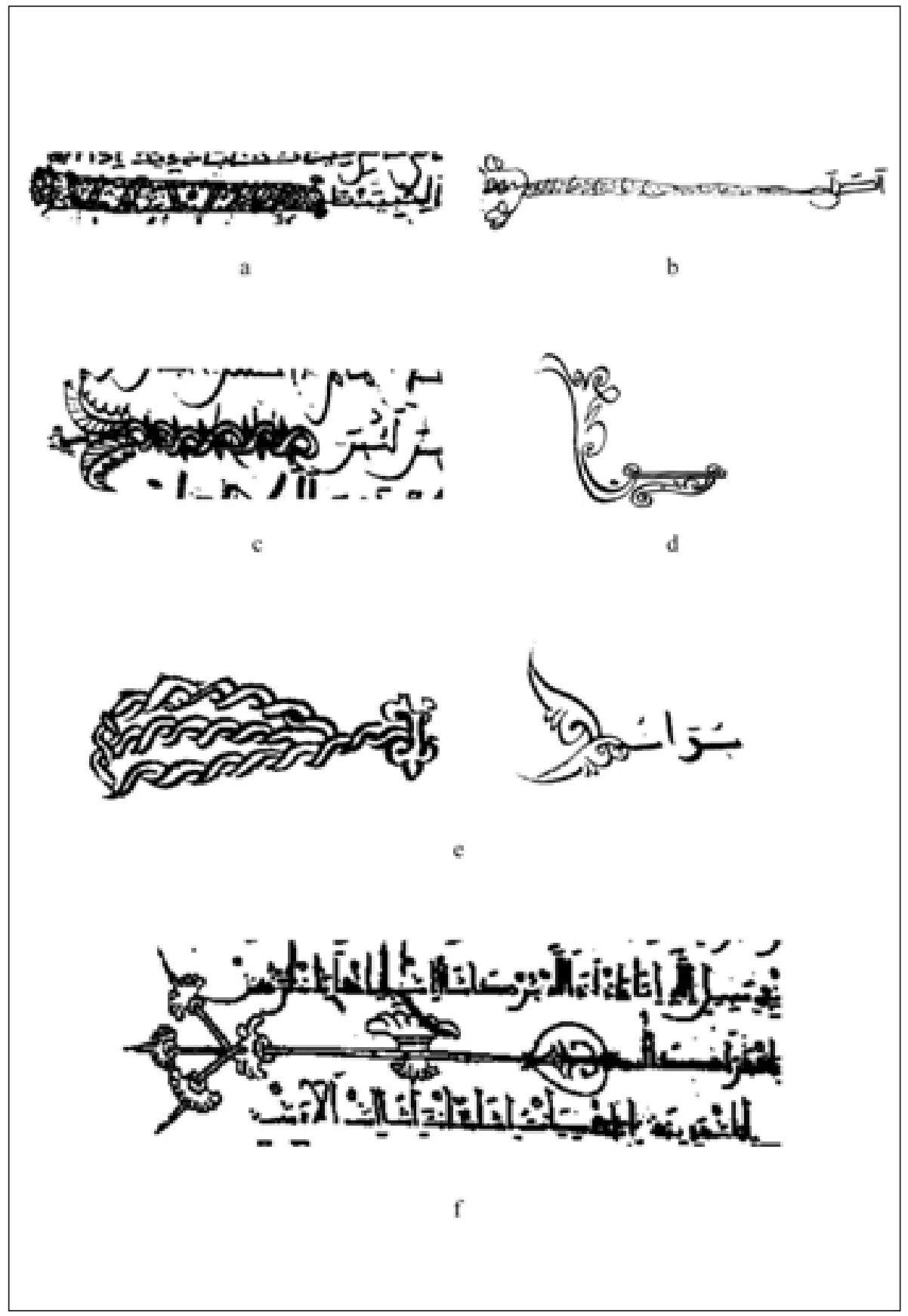

Ilustración V. 


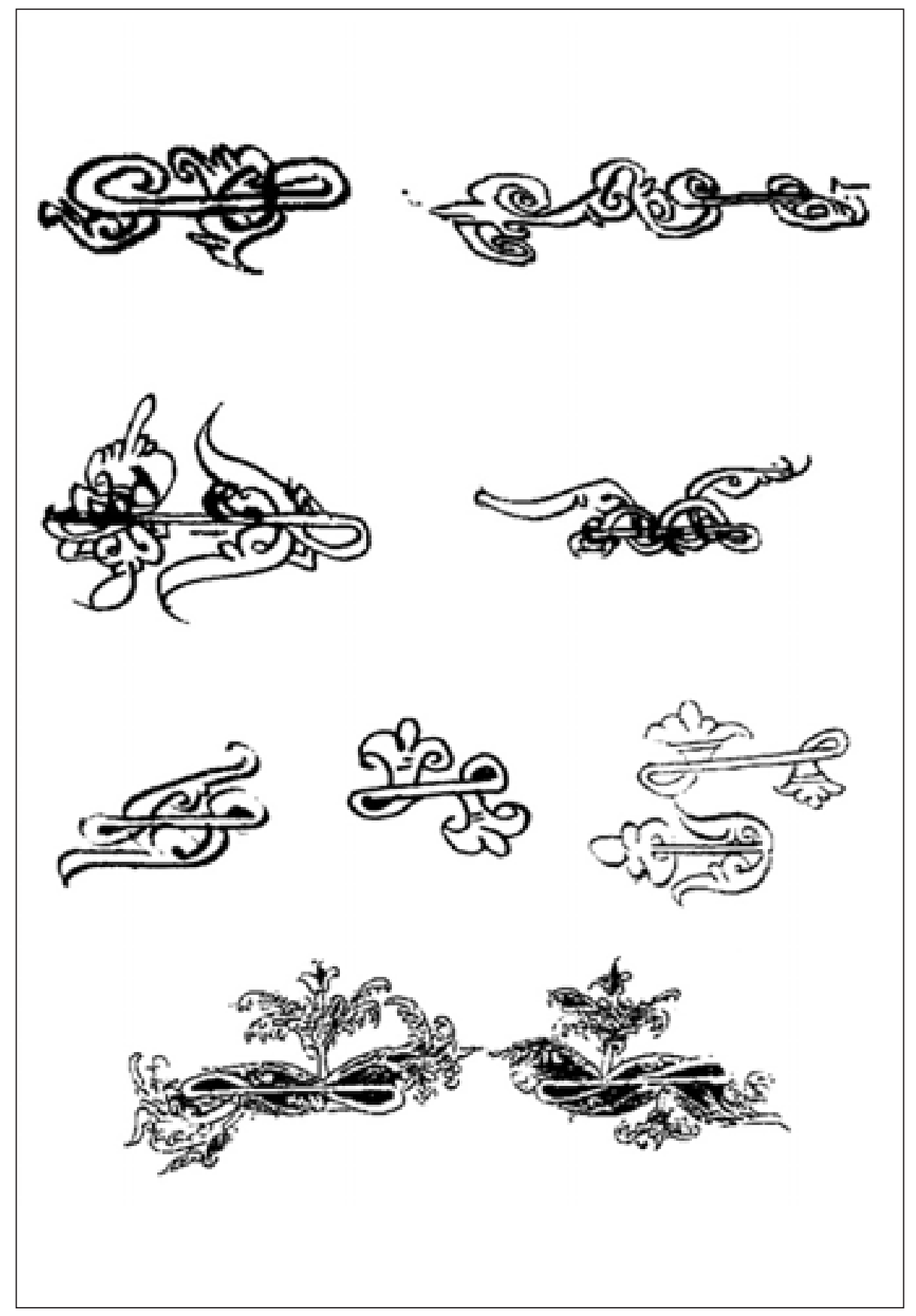

Ilustración VI. 
atención sobre ellas, o simplemente como decoraciones semi-marginales. Traemos varios ejemplos, con diversas formas que derivan de los elementos anteriores.

En un primer grupo mostramos aquellos que sirven para completar espacios en blanco o frases. Los dos primeros (Ilustración V.a y Ilustración V.b) son del J. III, el tercero (Ilustración V.c) es del J. IV; en cuarto lugar, sacamos del J. I (Ilustración V.d) un elemento semi-floral, que se eleva tras complementar la frase a la que pertenece; después se pueden ver dos elementos del J. XXII (Ilustración V.e) y el último pertenece al manuscrito que mayor calidad estilística tiene en sus decoraciones, que es el J. LI (Ilustración V.f).

En un segundo grupo, exponemos sencillos elementos que se distribuyen por el texto, que tienen diversas formas que vamos a agrupar en un mismo conjunto denominado Ilustración VI, que pertenecen a los manuscritos I, III, XIV, XXII; XXVI, XXIX y XXXIX. Vemos que el motivo de media palmeta y flor de lis es el que más se repite.

\section{ROSETONES. ILUSTRACIONES VII Y VIII}

Este motivo decorativo es habitual en la decoración de manuscritos andalusíes, como hemos comprobado de forma breve anteriormente. Se puede decir que son elementos casi exclusivos de los manuscritos alcoránicos. Además de su función estética tienen también diversas funciones prácticas: la de marcar cinco versículos, con la palabra "hams" o indicar el lugar donde ha sido revelada al profeta la azora ${ }^{28}$.

La circunferencia, según recoge el Corán, "representa el Cielo y la perfección, así como la eternidad [...], es también símbolo de la limitación adecuada, de lo preciso y regular, del mundo manifiesto. Para los alquimistas es símbolo de la unidad interna de la materia y la armonía universal. El hecho de incluir seres, objetos o figuras, señala determinación y delimitación. Estos peligros exteriores se encarnan, en las tradiciones musulmanas, en los "unūn, genios o demonios reconocidos y tratados por el Corán" ${ }^{29}$.

Podemos incluir en este grupo dos tipos de desarrollos decorativos: uno más circular y otro con forma de hoja o gota, según se quiera analizar. En cuanto a su posición en el texto puede ser marginal, para lo que sirven las funciones anteriormente citadas, o a veces, en menor tamaño, en medio del texto para separar los versículos, al igual que el motivo de "trébol o flor trilobulada" del que hablaremos más adelante.

28. S. KHEMIR, «Las artes del Libro»; J. DodDS y otros, Al-Andalus. Las Artes Islámicas en España, p. 116.

29. J.A. Souto LASALA, «Algunos signos mágicos musulmanes en la cerámica verde y morada de Termal (siglos XIII-XIV)», Actas del Colloque Internacional de Glyptographie de Saragosse, 1982, pp. $469-476$. 


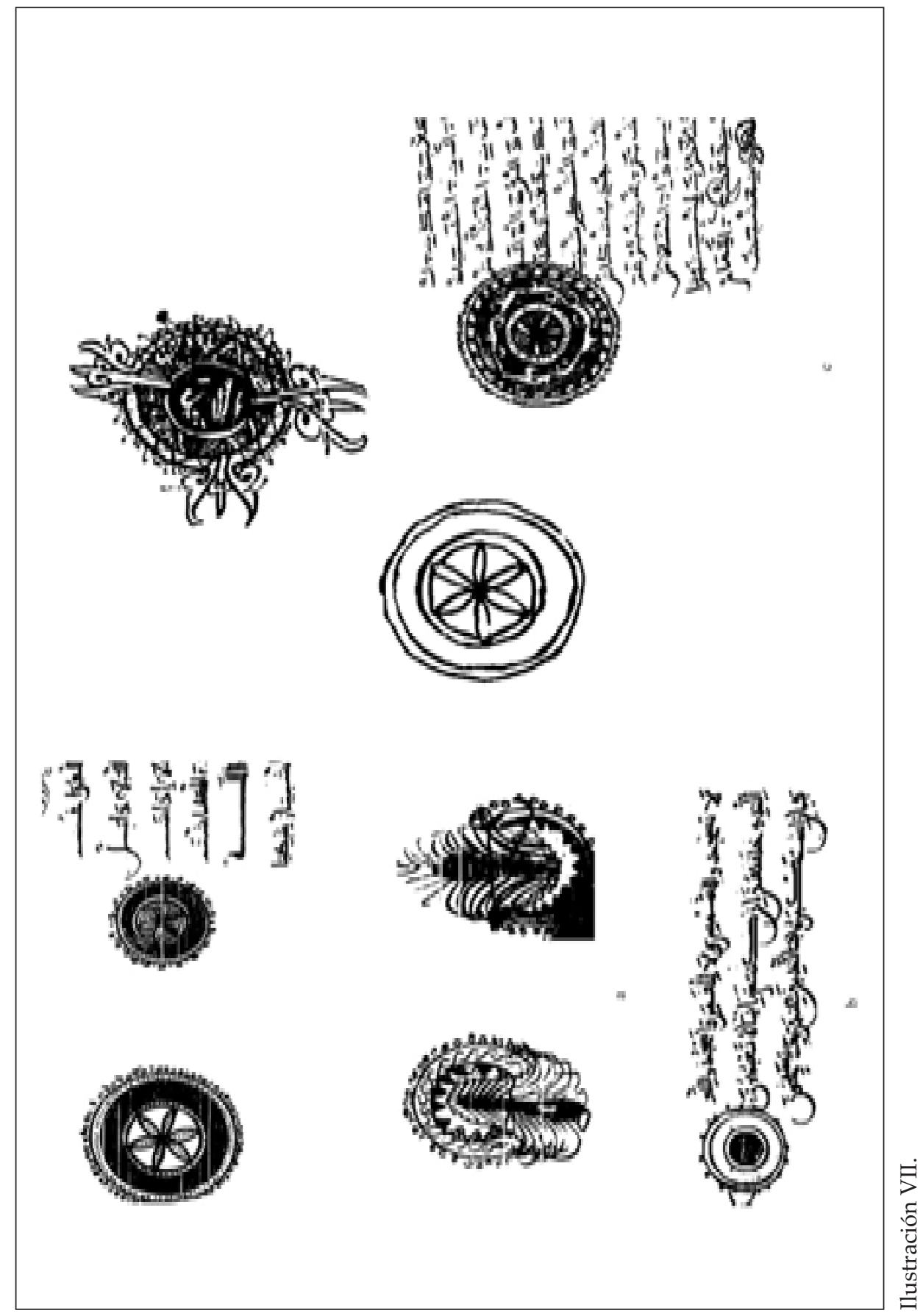


Queremos hacer, antes de irnos a los ejemplos moriscos, un recordatorio de los rosetones andalusíes anteriormente citados, donde podemos ver que este sistema de apoyo a la lectura es copiado por los moriscos de los libros que ellos conocen, estudian y copian, como es el Corán. Y esto nos lleva además a comprobar que el sistema de lectura o de apoyo a él va estrechamente ligado a la decoración y estética de dichos elementos, estética que a su vez parece responder a toda una simbología que muy posiblemente conocían los moriscos, gracias al estudio, traducción y copia de manuscritos andalusíes anteriores a ellos.

En los manuscritos aljamiados de la Junta, el formato más habitual de rosetón es el circular, a veces derivado en una pequeña forma puntiaguda que estiliza la imagen. Algunos, como los del manuscrito J. IV, son círculos que se rodean por pequeñas "bolitas", e insertan en su interior una flor geométrica de seis pétalos. Del mismo manuscrito (Ilustración VII.a) hemos sacado también otro tipo de forma marginal, con la misma función que los rosetones anteriores, pero que evoluciona de su forma circular como en una especie de "palmera" o ramificación. También en situación marginal en el texto. Otro ejemplo similar es el del manuscrito J. XVI (Ilustración VII.b).

En el J. I (Ilustración VII.c) también encontramos varios tipos de rosetones, desde el más simple, con una sola flor de seis puntas en su interior, hasta un rosetón con desarrollo floral, del tipo de los cartuchos anteriores, y unas medias palmetas que salen hacia el exterior estilizando la figura.

Como llevamos apuntando en todo el trabajo, el manuscrito J. LI es en el que mayor exquisitez estética encontramos, donde se han cuidado cada uno de los elementos, que se nos muestran con gran originalidad y belleza, respecto a manuscritos mudéjar-moriscos de esta colección y otras que hemos consultado. Los rosetones que mostramos en esta ocasión, Ilustración VIII, son elementos circulares que se abren, arquean y despliegan hacia el exterior con motivos florales, puntiagudos o con manos que señalan una frase o palabra concreta. Cada uno de ellos con una palabra escrita en cúfico en su interior, y alrededor todo un desarrollo floral creado por dobles y medias palmetas. También a veces son medios rosetones los que aparecen para marcar frases determinadas, como los que veremos más adelante.

Los rosetones o elementos marginales más curiosos y más llamativos de época andalusí nos parece encontrarlos en el ya citado Corán Smith-Lesoeuf, conservado en la Biblioteca Nacional de París, así como el Corán del siglo XII conservado en el Spink College de Londres, realizado en el Norte de África, donde podemos ver elementos situados en los márgenes, espacios que se dejan conscientemente para este fin, de gran desarrollo artístico y conocimiento estético, así como rosetones con función separadora; de él hay una foto muy ilustrativa en el libro El Islam, Arte y Arquitectura de la colección Könemann ${ }^{30}$.

30. VV.AA., El Islam, Arte y Arquitectura, Könemann, 2001, p. 19 


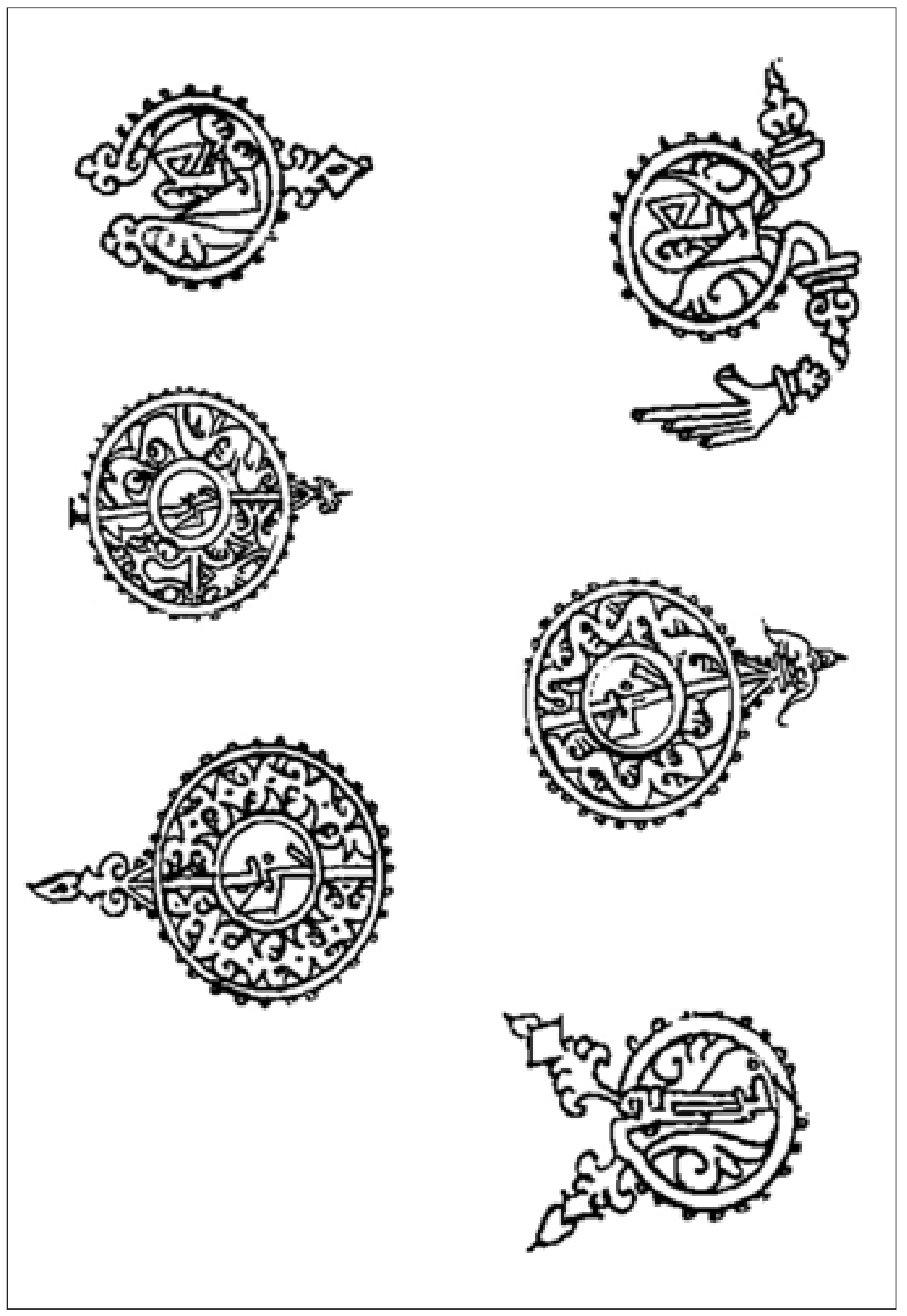

Ilustración VIII. 


\section{MANOS. ILUSTRACIÓN IX}

Un elemento de gran originalidad que aparece en los manuscritos mudéjares o moriscos es el de las manos. Habitualmente se sitúan en los márgenes de las obras para marcar frases o palabras concretas. Las encontramos en obras de muy diversa temática y de formas muy diversas.

Es un símbolo muy llamativo, porque sus significaciones son variadas. En la tradición bíblica y cristiana la mano es símbolo de poderío y supremacía. También se la suele relacionar con la tradición de Abraham. Se compara con el ojo, "ve también"; y según San Gregorio Niseno, las manos del hombre están igualmente ligadas al conocimiento, a la visión, pues tienen por fin el lenguaje. La mano es símbolo de acción diferenciadora: "su significación se junta con el de la flecha y recuerda que el nombre Quirón, el Sagitario, cuyo ideograma es una flecha, viene de la palabra mano" (VIRI, 193). La mano es como una síntesis exclusivamente humana de lo masculino y lo femenino, es pasiva en lo que contiene. Sirve de arma y utensilio; se prolonga por sus instrumentos ${ }^{31}$. Sin olvidar la relación directa con la mano de Fátima, que se nos aparece tanto con la palma totalmente abierta o con el dedo índice señalando algo, como en estos manuscritos.

Parece un elemento introducido por los almohades en la Península, traído del norte de África, "siendo las cerámicas esgrafiadas de la primera mitad del siglo XIII las que más tempranamente la documentan en la Península" ${ }^{32}$.

Traemos varios ejemplos en un mismo grupo, Ilustración IX, de manos de varios manuscritos, las funciones de casi todas ellas son las mismas, aunque en algunos ejemplos encontraremos que se sitúan junto al texto, sustituyendo las funciones de los elementos separadores y complementándolo, como la mano con el brazo alargado del manuscrito J. VIII (Ilustración IX.b).

Las características básicas de estas manos moriscas son la constante postura de señalar con el índice, el puño o muñeca que resalta tras la mano con una forma de red (ver imágenes del grupo IX.a) o con un motivo floral como las manos del J. LI (Ilustración IX.c).

Pavón Maldonado dice al hablar de los símbolos en el arte hispanomusulmán ${ }^{33}$, aunque en los ejemplos que él pone (mano de la Puerta de la Justicia de la Alhambra, mano del vaso granadino conservado en Leningrado, de cerámica de Talavera de la Reina, etc., todas de palma abierta con los cinco dedos a la vista), no hay ninguna mano similar a las de los manuscritos de la Junta, pero puede guiarnos un poco: "Para comprender mejor el significado de las

31. J. Chevalier, Diccionario de los símbolos, colab. de A. Gheerbrant, Barcelona, Herder, 1991, pp. 684-685.

32. J.A. Souto Lasala, op. cit., p. 465.

33. B. PAVÓN MALDONADO, «Arte, símbolo y emblemas en la España musulmana», Al-Qanțara, VI, 1985, pp. 397-449. 


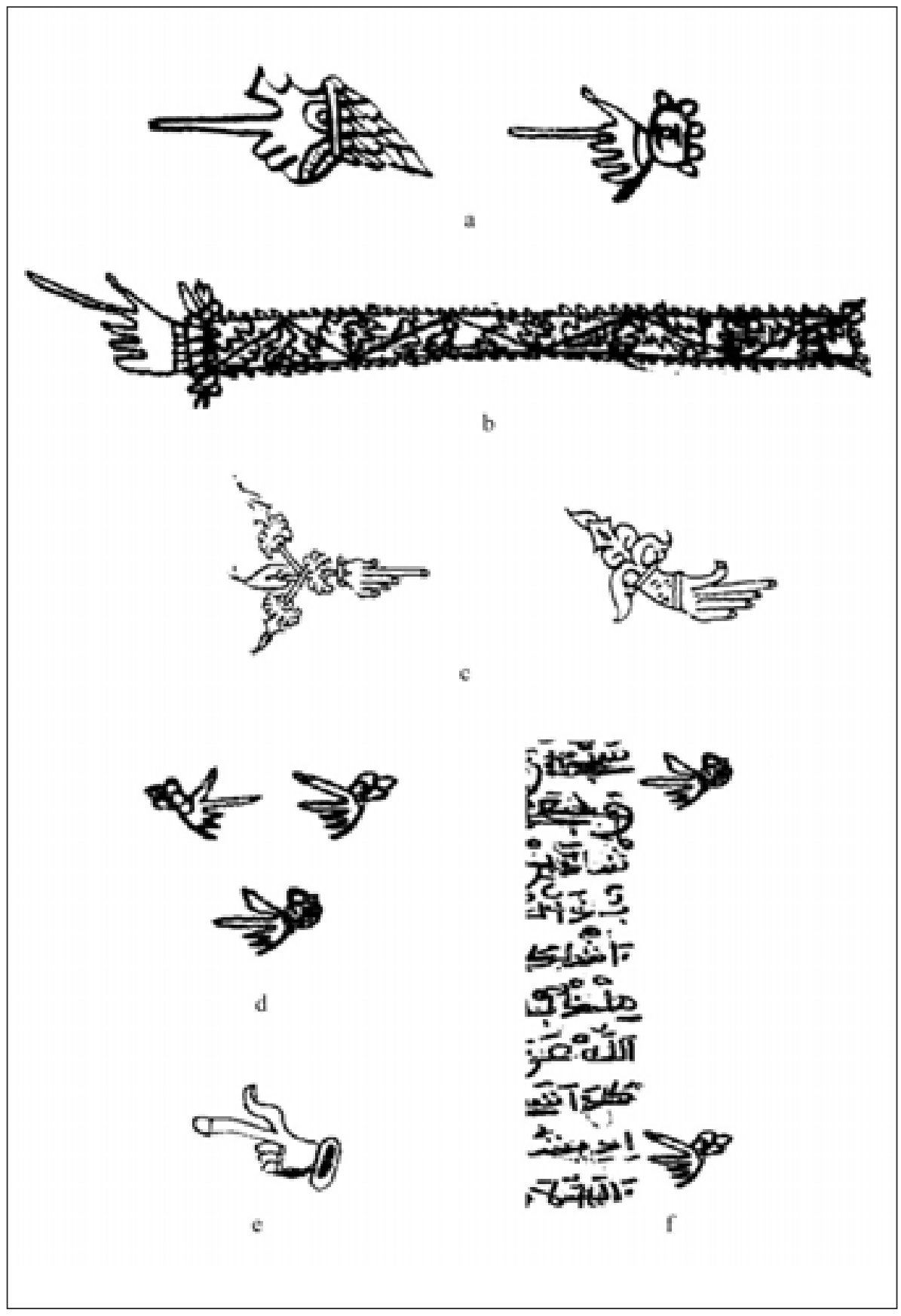

Ilustración IX. 
manos hispanomusulmanas no está de más traer aquí una breve tabla de aquellas interpretaciones más generalizadas que ha tenido la mano en la Antigüedad, ya sea exenta o con el brazo", es entonces cuando numera unas cuantas, pero continúa después: "a la llegada del Islam serían adoptadas las interpretaciones 2 (y cito: mano como símbolo de la divinidad que beneficia o da protección a sus adoradores) y 3 (cito: mano talismán que libera de los malos espíritus y del mal ojo)".

Y como decíamos antes es un elemento habitual, encontramos manos en algunos manuscritos moriscos en la Biblioteca de Cataluña $(680)^{34}$, hay un "códice Religioso aljamiado", de finales del siglo XVI o principios del XVII, donde hay manos marginales del mismo tipo que las que acabamos de ver en la $\mathrm{Bi}$ blioteca de la Junta, desde donde reafirmamos la originalidad.

\section{EPIGRAFÍA DESTACADA EN CÚFICO Y / O DECORADA. ILUSTRACIÓN X}

La intención de este motivo del que hablamos ahora es destacar los títulos o frases de una forma muy concreta. Aunque en el caso de los manuscritos moriscos las formas son más tradicionales o simples, imitan los manuscritos andalusíes, que utilizan el cúfico ${ }^{35}$ y la decoración de estas letras, ya sea al rellenar cada una de ellas con color, habitualmente en oro o dorado, o adornando el título con motivos florales. De este último recurso tenemos varios ejemplos en esta colección procedente de Almonacid de la Sierra, por ejemplo en el manuscrito J.III (Ilustración X.a), en el que vemos este uso un poco arcaico del cúfico, sin refinamiento o trabajo profesional de calígrafo, y se nota que imitan otros libros decorados que pueden haber conocido, pero sin gran dominio de la decoración ni de la iluminación. En el mismo grupo (Ilustración X.b), vemos un título del J. XXIV en el que la decoración casi ha consumido la lectura de las letras, las ha convertido más en imágenes o símbolos que en epigrafía.

Consultando todos aquellos manuscritos hallados en Fustat, Egipto, a través del estudio que hace Ernst Grube, y donde muestra muchos de estos fragmentos, hay uno realizado sobre papiro donde se conserva una escritura cúfica muy similar a la que muestro del manuscrito J.III, decorada con pequeños elementos florales por encima y debajo una escritura, se trata de una basmala $^{36}$, intencionadamente resaltada de esta forma.

El J. XXXIII también nos da una idea de este tipo de decoración para resaltar las letras y los títulos. Queremos citar además para comparar con estas decoraciones epigráficas varios coranes de distintas épocas que las contienen para sus

34. J. GiraLt, op. cit., pp. 119 y 198 (ilustración 20).

35. B. SовH BASSAM, El cúfico andalusí como ornamento: forma y símbolo, Tesis Doctoral, Universidad de Salamanca, 1998.

36. E. Grube, Studies in Islamic Painting, Londres, The Pindar Press, 1995, p. 79 (ilustración 150). 


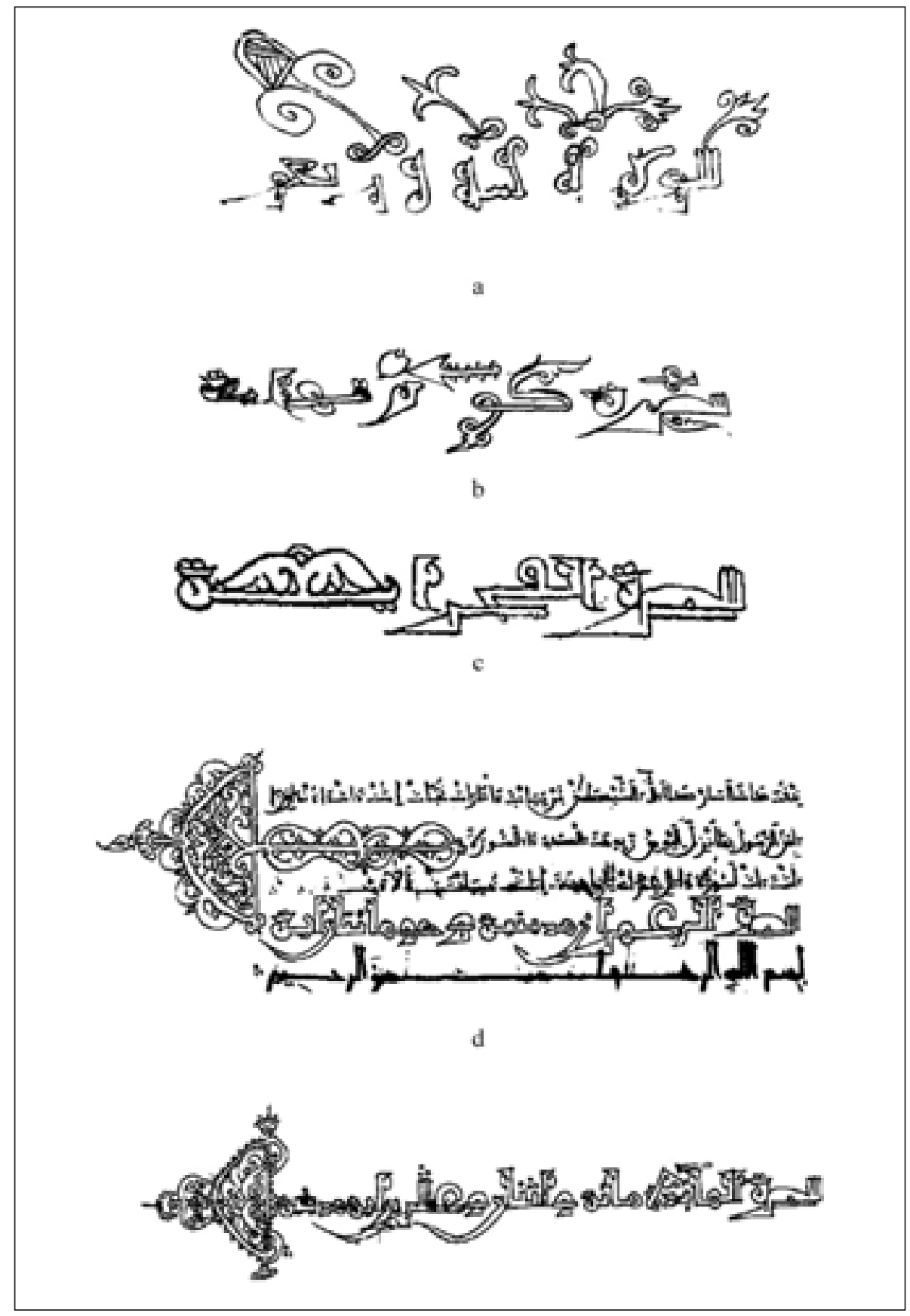

Ilustración X. 
títulos. Por ejemplo, en la Real Academia de la historia conservamos el Manuscrito $\mathrm{LV}$, de la colección de manuscritos árabes de la colección Pascual Gayangos ${ }^{37}$, en el que además de los títulos en dorado y en un cúfico muy cuidado y elaborado, vemos de nuevo esos rosetones laterales de gran delicadeza, casi igual que el Corán del que hemos hablado conservado en la Biblioteca de la Universidad de Estambul. En el J. LI (Ilustración X.d) vemos esta idea, pero la decoración lateral que acompaña el título en cúfico, es una media roseta o medio rosetón.

Volvemos a ver de nuevo la imitación de estas formas y de estos verdaderos sistemas de decoración, que crean una característica común en los manuscritos decorados de la Península, y que nos pueden llegar a mostrar toda una evolución, influenciada por factores políticos, sociales y económicos, desde al-Andalus a la España de los moriscos del siglo XVII.

\section{TRÉBOLES Y CEREZAS. ILUSTRACIONES XI Y XII}

En este apartado vamos a hablar de unos elementos que parecen unir aún más la tradición decorativa y estética de la ilustración de manuscritos árabes en la Península Ibérica. Como ya vimos más arriba, los pequeños elementos trilobulados, tréboles o pequeños círculos o elementos, a veces denominados hojas, a veces gotas, otras incluso llamas, se van extendiendo por el texto a leer, de forma que además de las múltiples funciones que aportan le dan un ritmo especial y una riqueza preciosista al libro.

Además, estos pequeños elementos aparecen en casi todos los manuscritos árabes y aljamiados de muchas colecciones. Y sus funciones son mucho más variadas que los elementos anteriores.

Agrupamos en la Ilustración XI este tipo de elementos decorativos, en primer lugar las decoraciones que denominaremos tréboles, que son las más habituales. Para ello traemos, y no analizaremos cada una de ellas ya que asemejan entre sí, del manuscrito J. I, del J. II, J. XIV, J. XXII y del J. LI, que tantas veces estamos reproduciendo en este trabajo. La simbología del trébol, como elemento de buena suerte, parece presente en todas las civilizaciones, quizás sea una de las razones por las que lo vemos tantas veces representado, si sumamos la tendencia de los moriscos por estas supersticiones se nos abre todo un camino de suposición ante estos pequeños símbolos, pero también la forma de una "flor de tres pétalos" sea la simple razón de sus existencia y durabilidad en la historia de las representaciones sobre manuscritos.

La cereza más bien parece una evolución de la otra imagen, ya que no la hemos encontrado en manuscritos ilustrados anteriores que hemos consultado.

37. Según la catalogación que nos ofrece E. Terés Sádaba, Los Manuscritos árabes de la colección de la Real Academia de la Historia: la Colección Pascual Gayangos, discurso leído en el acto de recepción pública, contestado por Emilio García Gómez, Madrid, 1975. 
Parece utilizarse más en libros de cuentas, poesías, para separar los versos o en libros religiosos sobre comentarios o estudios del Corán, en cambio el trébol y la gota se encuentran, junto al círculo simple, más en textos coránicos. Las cerezas, que tienen un significado más simbólico en Oriente, se utilizan en estos manuscritos casi siempre al final de las frases, como puede verse en la Ilustración XII, donde reagrupamos algunos de los ejemplos para que se pueda ver el formato habitual o posición normal de este elemento decorativo.

Para Hipólito Escolar, el libro aljamiado entra dentro de los libros curiosos, pero quizás debería de empezar a tenerse en cuenta, para poder conocer mejor, no sólo la sociedad de los siglos XV; XVI y XVII, sino también la literatura que manejan en el momento, sus conocimientos de libros antiguos o anteriores de sus antepasados andalusíes.

La realidad es que aún queda trabajo filológico por hacer sobre algunos de estos manuscritos aljamiados, trabajo que se está iniciando poco a poco, y que esperamos nos ayude un poco más a comprender estos libros, sus decoraciones y sus intenciones decorativas.

Como solución previa, para nosotros la decoración de los libros responde a unas claras intenciones estéticas y prácticas. Por un lado las estéticas responden directamente a una búsqueda del honor y el orgullo musulmán por seguir considerándose como tales, al igual que sus antepasados, ya que podemos constatar que conservarían libros andalusíes, los estudiarían y los copiarían, no hay más que ver la continuidad artística de los elementos mostrados. Y la función práctica, ahora más que nunca, acompaña la función didáctica de copiar y, sobre todo, de traducir estas obras al castellano romance para acercarlas a los musulmanes moriscos españoles, en este caso aragoneses, que tanto sufrían por poder conservar su religión de la forma más auténtica. Ese sentimiento de pesar y profunda pena que parece que le produce al Mancebo de Arévalo, cuando "visitó el perdido sur de al-Andalus en el siglo XV al contemplar la que describe como dulce y hermosa tierra, rica en pan y aceitunas, agua y oro" ${ }^{\prime 38}$.

Además la conclusión primera que sacamos de este estudio es la idea básica de una continuación en la decoración de manuscritos, en formas y en soluciones prácticas, como antes apuntamos. Una continuidad que podremos ir demostrando más adelante con el descubrimiento y estudio de otros manuscritos aún inéditos en este tipo de tesis. Así que podemos también asegurar que los moriscos de los siglos XVI y XVII tenían en sus manos libros de sus antepasados o conocían aquellos libros, a los que admiraban y copiaban para perpetuar su cultura, como una identidad única, que sentían y que mostraban decorando y embelleciendo sus libros a pesar de las complejas condiciones de vida que sufrieron en muchas ocasiones.

38. SAAVEDRA, op. cit., p. 155. 


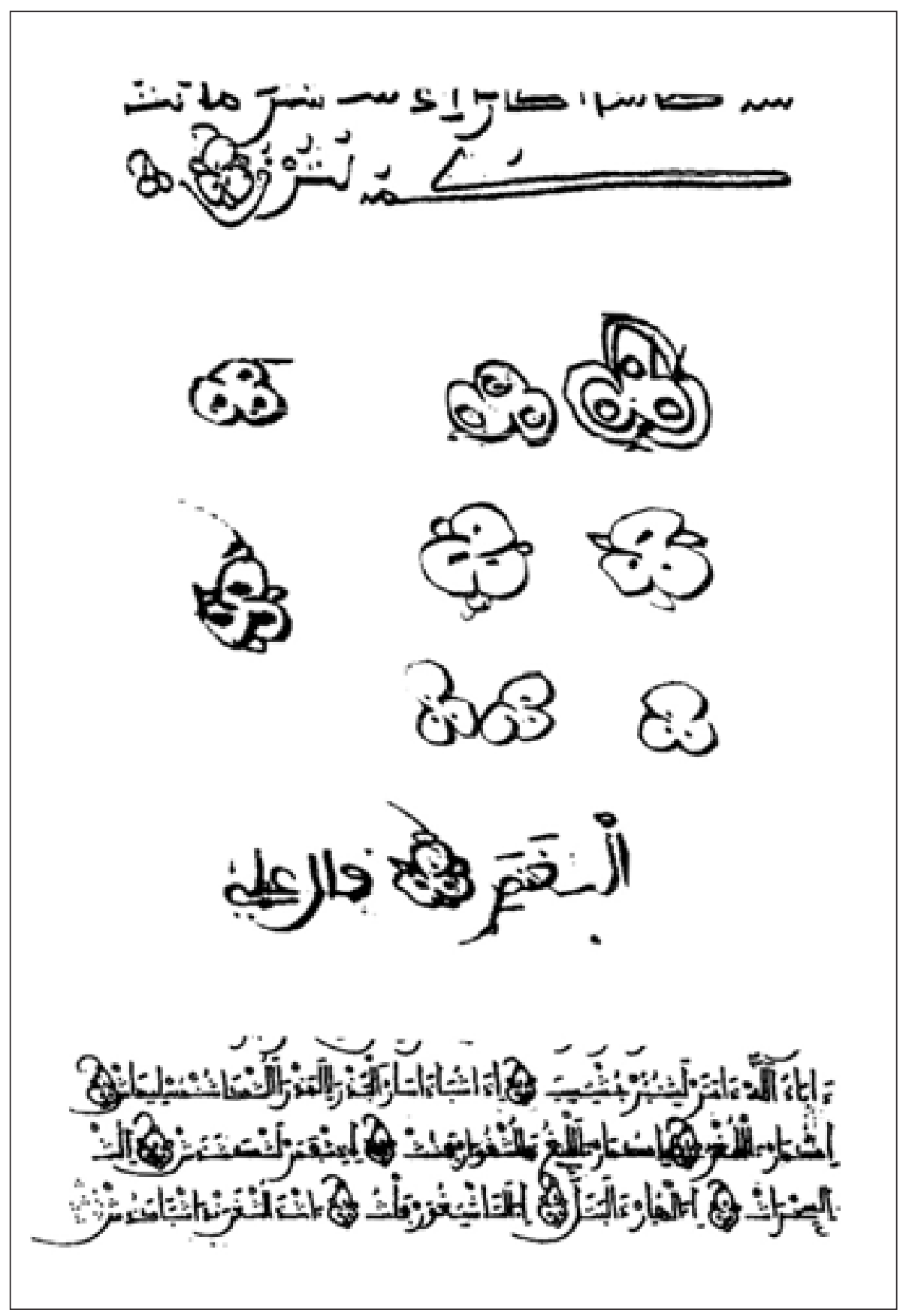

Ilustración XI. 
Sharq al-Andalus, 19 (2008-2010)

Ana Isabel Beneyto Lozano

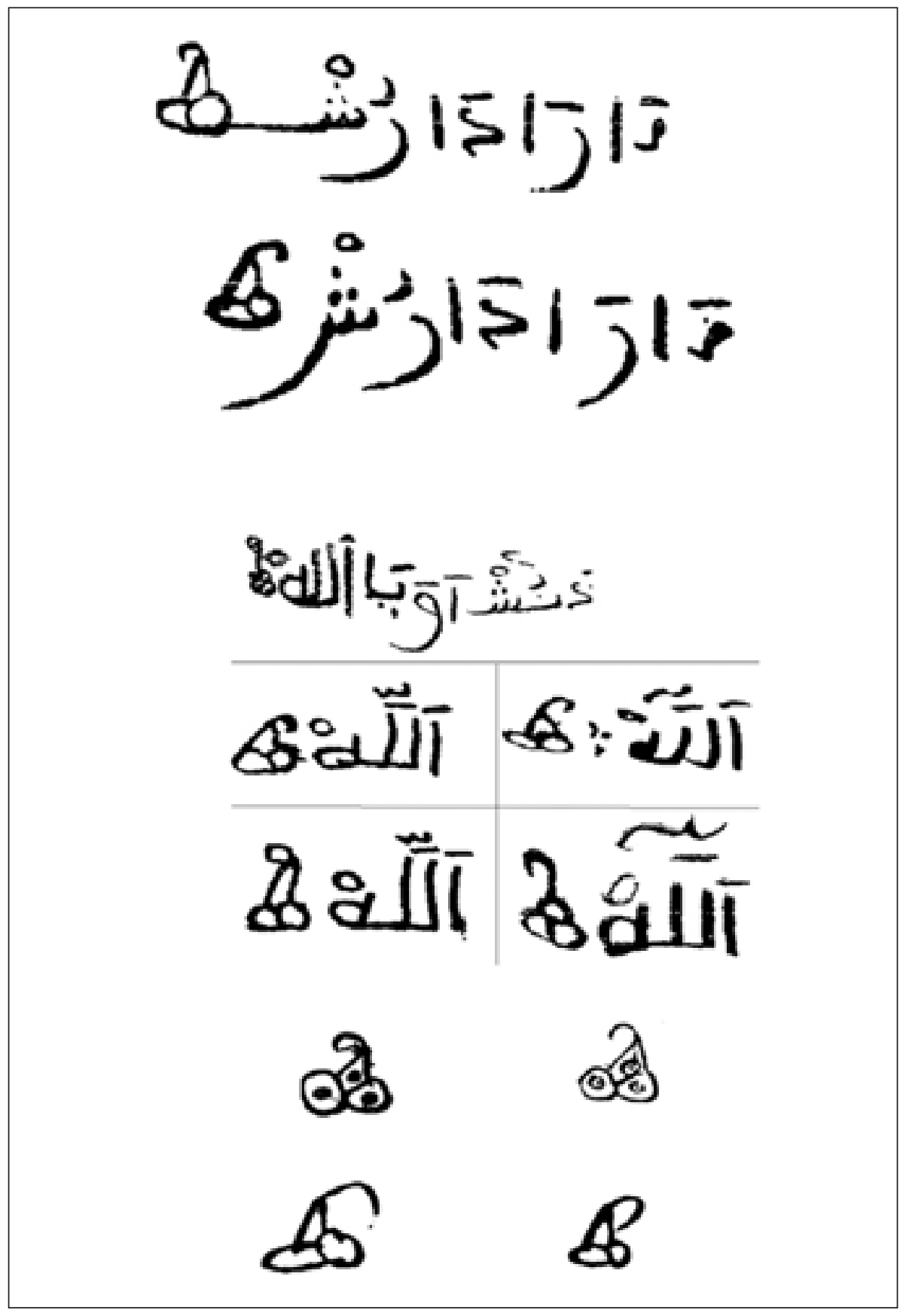

Ilustración XII.

232 


\section{RESUMEN}

El hallazgo de más de un centenar de manuscritos de origen mudéjar y morisco al tirar una de las paredes de una casa de la población de Almonacid de la Sierra, situada en la provincia de Zaragoza, ha sido uno de los más importantes descubrimientos de manuscritos hispano-árabes, hasta ahora. En este artículo se analizan las ilustraciones de dichos manuscritos, sus funciones y posiciones del texto. Así se quiere mostrar la importancia del ornamento y decoración de manuscritos en la Península durante la dominación árabe, y cómo este concepto se ve reforzado por la continuidad de los moriscos en decorar sus libros; una continuidad que se puede ver estilística y formalmente, desde los andalusíes hasta los últimos moriscos antes de ser expulsados.

\section{ABSTRACT}

The discovery of more than a hundred of mudejar and morisco manuscripts when the wall of a house in Almonacid de la Sierra (Saragossa) were knock down, has been one of the most important. In the article the ilustrations of these manuscripts will be analyse, also its functions and position in the text. So we want to show the importance of the ornament and decoration in the Iberian Peninsula under Arab rule, and this concept will be reinforce by the moriscos continuity decorating their books; a continuity that could be seen in a stylistic way, from the andalusians to the last moriscos before been expelt. 